\title{
PERUBAHAN SOSIAL TERHADAP PENGGUNA HANDPHONE DI KALANGAN REMAJA KOTA MATARAM \\ (Kajian Menurut Undang-Undang No. 36 Tahun 1999 Tentang Telekomunikasi)
}

\author{
Abdul Sakban \\ Dosen Pendidikan Pancasila dan Kewarganegaraan \\ FKIP Universitas Muhammadiyah Mataram
}

INFO ARTIKEL
Riwayat Artikel:
Diterima: $09-09-2016$
Disetujui: $30-09-2016$
Kata Kunci:
$\begin{aligned} & \text { Perubahan Sosial, } \\ & \text { Pengguna Handphone, } \\ & \text { UU No. } 36 \text { Tahun } 1999\end{aligned}$

Diterima: 09-09-2016

Disetujui: $30-09-2016$

\begin{abstract}
ABSTRAK
\end{abstract}
\section{A. LATAR BELAKANG}

Apa yang berubah terhadap manusia?, perubahan yang terjadi pada manusia secara struktural dipengaruhi oleh perilaku social dan interaksi social. Perubahan social ini sering dialami oleh individu-individu, kelompok-kelompok yang berkembang di masyarakat, apalagi pada abad 21 ini perkembangan teknologi dan informatikan sangat pesat, sehingga dapat mempengaruhi perilaku seseorang dengan adanya teknologi yang canggih, mudah dan praktis. Perilaku social merupakan sebuah sikap yang tetap melekat pada diri seseorang yang kadang-kadang selalu berubah terhadap perubahan dan perkembangan teknologi seperti adanya alat komunikasi ponsel, handphone, computer, TV dan sebagainya yang baru dan canggih, sehingga menarik keinginan seseorang untuk memilikinya sebagai hak milik pribadi.

Interaksi social merupakan hubungan manusia dengan manusia lainnya dan hubungan manusia dengan lingkungan sebagai wadah untuk beradaptasi dalam kehidupan sehari-hari. Hubungan antara individu satu dengan individu lainya ini bisa menjadi motif terjalinnya hubungan sahabat yang baik dan bisa juga menjadi motif terjadi kejahatan. Apalagi di jaman sekarang fenomena berawal dari sahabat yang baik bisa menjadi kejahatan yang terencana atau kejahatan yang tidak direncanakan melalui komunikasi handphone. Disamping itu, handphone bisa menjadi factor mempengaruhi turunnya motivasi belajar siswa atau remaja, prestasi belajar, dan bahkan bisa merusak hubungan social antara sesama teman sejawat dan bahkan juga anggota keluarganya sendiri dan lebih-lebih orangnya mereka sendiri.

Fenomena di atas merupakan suatu peristiwa perubahan perilaku social dan interaksi social yang buruk dan tidak beretika terutama untuk kaum kalangan remaja. Oleh karena itu, Indonesia merupakan Negara yang berazaskan Negara hukum, sehingga segala perilaku warga negara harus diatur menurut UndangUndang Dasar Negara Republik Indonesia 1945 sebagai alat pengontrol social, sehingga terjalinnya kehidupan yang aman, adil dan makmur. Demikian juga diterbitkan oleh anggota legislative tentang UU No. 36 tahun 1999 tentang telekomunikasi yang berfungsi mengatur pihak penyelenggara seperti BUMN, BMUD, Badan Hukum Swasta, dan Personalia sehingga proses dapat dilakukan secara teratur dan tidak merugikan salah satu pihak. Tujuan diundangkan UU No. 36 tahun 1999 tentang telekomunikasi adalah untuk mendukung persatuan dan kesatuan bangsa, meningkatkan kesejahteraan dan kemakmuran rakyat secara adil dan merata, mendukung kehidupan ekonomi dan kegiatan pemerintahan, serta meningkatkan hubungan antarbangsa. 
Tujuan dalam penulisan makalah ini adalah untuk mengetahui dampak penggunaan handphone di kalangan remaja, dan untuk mengetahui tinjauan UU No. 36 Tahun 1999 Tentang Telekomunikasi terhadap pengguna handphone di kalangan remaja.

\section{B. METODE PENELITIAN}

Penelitian ini menggunakan penelitian yuridis normative, dengan pendekatan pada studi dokumen dalam penelitian kepustakaan untuk mempelajari data sekunder di bidang hukum yang berhubungan dengan permasalahan dan tujuan penelitian ini. Pendekatan yang digunakan adalah pendekatan konseptual dan pendekatan historis (Marzuki, 2005: 117). Pendekatan konseptual dalam penelitian ini dimaksudkan untuk mencari dasar penggunaan alat telekomunikasi yang berasal dari UU No. 36 tahun 1999 yang relevan serta doktrin-doktrin hukum positif. Pendekatan historis dilakukan dalam kerangka pelacakan penggunaan alat telekomunikasi dalam hukum di Indonesia. Penelitian ini akan memfokuskan pada kota Mataram.

Penelitian ini menekankan pada data sekunder yang terdiri dari bahan hukum primer berupa ketentuan-ketentuan Undang-undang telekomunikasi yang terdokumentasi, bahan hukum sekunder yang diperoleh dari buku teks, jurnal, kasus-kasus hukum (Soekanto, 2010: 13).

Prosedur pengumpulan bahan hukum dilakukan melalui studi literatur dan studi dokumen sesuai dengan permasalahan yang telah dirumuskan untuk selanjutnya dikaji secara komprehensif. Pengolahan dan Analisis Bahan Hukum dilakukan dengan metode dogmatik hukum yaitu bahan hukum primer dilakukan dengan cara memahami teks dari bahan hukum kemudian dikaitkan dengan isi pengertian teks yang satu dengan yang lain yang menggambarkan penggunaan handphone dikalangan remaja menurut Undang-Undang No. 39 Tahun 1999.

\section{HASIL DAN PEMBAHASAN}

\section{Teori Perubahan Social}

Moore (1967:3) dalam Lauer (2003: 4) mendefinisikan perubahan social sebagai "perubahan penting dari struktur sosial", dan yang dimaksud dengan struktur social adalah pola-pola perilaku dan interaksi social.

Definisi lain, mengenai perubahan social menurut Harper (1989) dalam Martono (2012: 5-6) bahwa perubahan social diidentifikasikan sebagai pergantian (perubahan) yang signifikan mengenai struktur social social dalam kurun waktu tertentu. Menurutnya, perubahan di dalam struktur ini mengandung beberapa tipe perubahan struktur social, yaitu:

a) Perubahan dalam personal

Perubahan dalam personal, yang berhubungan dengan perubahan-perubahan peran dan individuindividu baru dalam sejarah kehidupan manusia yang berkaitan dengan keberadaan struktur. Perubahan dalam tipe ini bersifat gradual (bertahap) dan tidak terlalu banyak unsur-unsur baru maupun unsur-unsur yang hilang. Perubahan ini dapat dilihat misalnya dalam perubahan peran dan fungsi perempuan dalam masyarakat. Jika sebelumnya perempuan diposisikan sebagai subjek yang memegang peran dan fungsi di wilayah domestic (di dalam rumah), namun sebagai mana dapat dilihat dalam masyarakat modern, perempuan sudah mulai ikut berperan serta dalam wilayah public yang sebelumnya hanya diduduki lakilaki. Tentu saja perubahan ini membawa berbagai konsekuensi, seperti dalam masalah pengasuhan anak, harmonisasi keluarga, dan sebagainya.

b) Perubahan dalam cara bagian-bagian struktur social berhubungan.

Perubahan ini, misalnya terjadi dalam perubahan alur kerja birokrasi dalam lembaga pemerintahan. Bila pada masa dulu cara kerja aparat pemerintah masih manual (menggunakan tenaga manusia) maka sekarang dapat dilihat hamper berbagai system pelayanan pemerintahan telah tergantikan secara mekanis menggunakan teknologi canggih, sehingga segala sesuatu menjadi serba online. Hal ini memengaruhi perubahan cara kerja aparat pemerintah dalam memberikan pelayanan kepada public.

c) Perubahan dalam fungsi-fungsi struktur

Berkaitan dengan apa yang dilakukan masyarakat dan bagaimana masyarakat tersebut melakukannya. Pada masyarakat tradisional, keluarga memegang peran penting dalam menjalankan fungsi pendidikan, karena pada saat itu pendidikan masih berkutat dalam masalah transfer nilai antara orang tua dengan anak. Seiring perkembangan zaman, peran untuk memberikan pendidikan telah tergantikan lembaga pendidikan diluar keluarga, yaitu sekolah. Sekolah menjadi sebuah kebutuhan pokok bagi masyarakat modern.

d) Perubahan dalam hubungan struktur yang berbeda.

Lembaga pendidikan dalam masyarakat industry memiliki fungsi menyiapkan tenaga kerja untuk kepentingan industry. Hal ini mengakibatkan adanya saling keterkaitan antara lembaga pendidikan dengan dunia usaha, substansi (muatan) pendidikan pada saat sekarang lebih diarahkan untuk menyesuaikan kondisi atau kebutuhan dunia kerja.

e) Kemunculan struktur baru

Kemunculan struktur baru, yang merupakan peristiwa munculnya struktur baru untuk menggantikan struktur sebelumnya. Perubahan dalam hal ini dapat dilihat misalnya munculnya KPK (Komisi Pemerantasan Korupsi) namun dengan terbantunya KPK, peran kepolisian dalam melakukan penyelidikan masalah korupsi tergantikan.

Setiap perubahan social akan mengalami perubahan, apakah dipengaruhi oleh teknologi ataukah bukan, oleh karena itu bagaimana cara teknologi menyebabkan perubahan, Ogburn dan Nimkoff (1995) menemukan cara pendekatan pertama dalam upaya menerangkan berbagai perubahan dalam kehidupan keluarga. Ia berpendapat bahwa perubahan social dalam keluarga, mula-mula diketahui dengan menggunakan sekelompok ahli, dan kemudian 8 perubahan utama dipilih dari daftar yang disajikan oleh kelompok ahli itu. itu adalah:

Delapan jenis perubahan utama dalam keluarga

1. Penekanan yang semakin besar terhadap percintaan;

2. Perkawinan dalam usia yang semakin muda;

3. Anggota keluarga yang semakin kecil;

4. Jumlah istri yang bekerja semakin besar;

5. Kekuasaan orangtua yang semakin berkurang;

6. Pemberian perhatian terhadap anak semakin besar; 
7. Angka perceraian yang semakin besar;

8. Fungsi keluarga yang semakin mengecil (Lauer, 2003: 216-217).

Perubahan ini kemudian dirunut kaitannya dengan penemuan teknologi. Sebagai contoh, bagaimana cara kita dapat menerangkan melemahnya ikatan kekeluargaan di dalam keluarga modern? Mula-mula terdapat pengaruh handphone di kota satu dengan kota lain yang menyebabkan bisa berkomunikasi secara langsung meskipun berbeda wilayah atau daerah.

Veblen (1904) dalam Lauer (2003: 4) ia melihat tatanan masyarakat sangat ditentukan oleh teknologi, bahwa "Proses mesin merembesi kehidupan modern dan menentukannya dalam artian mekanik.... mesin telah menjadi tuan manusia yang bekerja dengannya dan telah menjadi hakim yang menentukan nasib kebudayaan komunitas yang hidup dengannya. Mesin adalah alat yang membuat orang menjadi sama-rata dan kasar yang bertujuan menghancurkan segala yang dihormati, dimuliakan dan yang dihargai dalam pergaulan dan yang dicita-citakan manusia”.

Berdasarkan pandangan Veblen ini, ia lebih memusatkan perhatian pada pengaruh teknologi terhadap pikiran dan perilaku manusia. Ia menyatakan, pola keyakinan dan perilaku manusia, terutama dibentuk oleh cara mencari nafkah dan mendapatkan kesejahteraannya, yang selanjutnya adalah fungsi teknologi.

Secara sosiologis, teknologi memiliki makna yang lebih mendalam daripada peralatan. Henslin (2006) yang dikutip Martono (2012: 278), teknologi menetapkan suatu kerangka bagi kebudayaan nonmaterial suatu kelompok. Jika teknologi suatu kelompok mengalami perubahan, maka cara berpikir manusia juga akan mengalami perubahan. Hal ini juga berdampak pada cara mereka berhubungan dengan yang lain. Bagi Marx, teknologi merupakan alat, dalam pandangan materialism historis hanya menunjuk pada sejumlah alat yang dapat dipakai manusia untuk mnecapai kesejahteraan. Weber mendefinisikan teknologi sebagai ide atau pikiran manusia itu sendiri yang dapat dimanfaatkan untuk kepentingan manusia itu sendiri. Selanjutnya juga, menurut Dukheim, teknologi merupakan kesadaran kolektif yang bahkan diprediksi dapat menggantikan kedudukan agama dalam suatu masyarakat (Martono, 2012: 278).

\section{Penggunaan Hanphone di Kalangan Remaja}

\section{a) Handphone}

Jamani dkk, (2013: 3) menyatakan telepon genggam (disingkat telgam) seringnya disebut handphone (disingkat HP) atau disebut pula sebagai telepon seluler (disingkat ponsel) adalah perangkat telekomunikasi telepon konvensional saluran tetap, namun dapat dibawa kemana-mana (portabel, mobile) dan tidak perlu disambungkan dengan jaringan telepon menggunakan kabel (nirkabel; wireless). Menurutnya, Handphone memiliki fungsi lain yakni berfungsi untuk melakukan dan menerima panggilan telepon, ponsel umumnya juga berfungsi pengiriman dan penerimaan pesan singkat (short message service, SMS).

Ada pula penyedia jasa telepon videophone, sebagai alat pembayaran, maupun untuk televisi onlinedi telepon genggam mereka. Sekarang telepon genggam menjadi gadget yang multi fungsi. Mengikuti perkembangan teknologi digital, kini ponsel juga dilengkapi dengan berbagai pilihan fitur, seperti bisa menangkap siaran radio dan televisi, perangkat lunak pemutar audio $\left(\mathrm{MP}_{3}\right)$ dan video, kamera digital, game, dan layanan internet (WAP, GPRS, 3G).

Selain fitur-fitur tersebut ponsel sekarang sudah ditanamkan fitur komputer. Jadi di ponsel tersebut, orang bisa mengubah fungsi ponsel tersebut menjadi mini komputer. Di jaman modern ini, handphone sangat dibutuhkan. Kehadiran telpon seluler (Ponsel) atau handphone telah merubah kehidupan manusia. Jarak selama ini dituding menjadi biang keladi kesulitan itu, tidak kuasa lagi menghalangi. Sebagian besar remaja jaman sekarang merasa dirinya sangat ketergantungan dengan handphone karena hal itu sangat membantu kemudahan hidup, khususnya komunikasi. Sebagian besar para remaja mengatakan bahwa tujuan utama menggunakan handphone; sebagai alat komunikasi dan sebagai penyambung silaturahmi dan hiburan. Tidak menutup kemungkinan sebagai media untuk menyampaikan pesan atau menyalurkan informasi dalam menambah wawasan menuju kemajuan kehidupan informal, formal, dan non formal.

Nikmah (2010: 4) menyatakan bahwa telepon genggam atau Handphone adalah sebuah perangkat telekomunikasi elektronik yang mempunyai kemampuan dasar yang sama dengan telepon fixed line sehingga konvesional namun dapat dibawa keman-mana (portable) dan tidak perlu disambungkan dengan jaringan telepon menggunakan kabel (nirkabel, wireless). Handphone saat ini memang bukan barang yang mewah dan aneh bagi masyarakat Indonesia.

Mazdalifah (2014) menyatakan penggunanan handphone telah menyebar sampai ke pelosok desa. Hal ini membuat sistem komunikasi mengalami perubahan, khususnya pada masyarakat pedesaan. Masyarakat lebih menyukai hal cepat dan praktis. Pesan yang panjang dan dalam berubah menjadi pesan yang singkat.

\section{b) Handphone sebagai Teknologi Pengubah Pola Komunikasi}

Arminen (2007) yang dikutip Hendrastomo (2008: 5) menyatakan bahwa penggunaan ponsel akan merubah cara kita berinteraksi berkomunikasi dengan individu lain dengan lebih bebas. Akan tercipta kebebasan yang "tanpa batas" ruang dan waktu yang memungkinkan individu berkomunikasi satu hari penuh. Sedangkan menurut Green yang dikutip Arminen, (2007) menyebut ponsel sebagai "Lazarus Device" yang dapat menutup momen/waktu mati (dalam Hendrastomo (2008: 5). Dengan kata lain hanphone mengisi waktu-waktu senggang/kosong. Interaksi orang bisa dilakukan dimana saja, ketika orang istirahat di malam hari pun handphone bisa menjadi media untuk tetap berkomunikasi. Jarak yang jauh menjadi tidak masalah ketikan ada hanphone.

Walaupun fungsi handphone yang mampu meningkatkan komunikasi antar individu, tetapi disisi lain akan muncul dampak negative, mulai dari etika berkomunikasi lewat handphone hingga komunikasi yang tidak kenal waktu justru mengganggu hak privat individu. Handphone juga bisa menghilangkan kohesi social karena terakdang ketika berada dalam situasi formal pun kemudian orang akan lebih mementingkan komunikasi via handphone.

Komunikasi via handphone kemudian memerlukan moralitas dan etika sebagai penyaring 
berjalannya proses komunikasi sehingga tidak justru menyingkirkan komunikasi dalam ruang public mengarah ke ruang privat, tetapi bagaimana mengoptimalkan peran handphone sebagai media untuk meningkatkan kualitas dan mendekatkan hubungan interpersonal. Menurut Foucault yang dikutip Barker (2008) dipertegas oleh Hendrastomo (2008: 6) moralitas terkait dengan system perintah dan larangan yang terbentuk dalam kaitannya dengan kode-kode yang diformalkan. Etika terkait dengan nasehat praktis tentang bagaimana orang harus menghubungkan satu diri dengan diri yang lain dalam kehidupan sehari-hari. Sehingga komunikasi handphone pun kemudian juga berada dalam ranah dan belenggu aturan etika dan moralitas yang menyertainya.

\section{Undang-Undang No. 36 Tahun 1999 Tentang Telekomunikasi}

Undang-Undang No. 36 tahun 1999 tentang telekomunikasi, bahwa alat komunikasi Handphone termuat di dalam pasal 9 berbunyi "penyelenggaraan telekomunikasi khusus dapat dilakukan perseorangan, instansi pemerintah, dan badan hukum selain penyelenggara jaringan telekomunikasi dan jasa telekomunikasi”.

Kemudian "telekomunikasi khusus", diatur pada bagian kesembilan Bab IV UU No. 36 Tahun 1999 sebagai berikut:

\section{Pasal 29}

(1) Penyelenggaraan telekomunikasi khusus sebagaimana dimaksud dalam Pasal 9 ayat (3) huruf a dan huruf b, dilarang disambungkan ke jaringan penyelenggara telekomunikasi lainnya.

(2) Penyelenggaraan telekomunikasi khusus sebagaimana dimaksud dalam Pasal 9 ayat (3) huruf c, dapat disambungkan ke jaringan penyelenggara telekomunikasi lainnya sepanjang digunakan untuk keperluan penyiaran.

\section{Pasal 30}

(1) Dalam hal penyelenggara jaringan telekomunikasi dan atau penyelenggara jasa telekomunikasi belum dapat menyediakan akses di daerah tertentu, maka penyelenggara telekomunikasi khusus sebagaimana dimaksud dalam Pasal 9 ayat (3) huruf a, dapat menyelenggarakan jaringan telekomunikasi dan atau jasa telekomunikasi sebagaimana dimaksud dalam Pasal 7 ayat (1) huruf a dan huruf b setelah mendapat izin Menteri.

(2) Dalam hal penyelenggara jaringan telekomunikasi dan atau penyelenggara jasa telekomunikasi sudah dapat menyediakan akses di daerah sebagaimana dimaksud pada ayat (1), maka penyelenggara telekomunikasi khusus dimaksud tetap dapat melakukan penyelenggaraan jaringan telekomunikasi dan atau jasa telekomunikasi.

(3) Syarat-syarat untuk mendapatkan izin sebagaimana dimaksud pada ayat (1) diatur dengan Peraturan Pemerintah.

\section{Pasal 31}

(1) Dalam keadaan penyelenggara telekomunikasi khusus untuk keperluan pertahanan keamanan negara sebagaimana dimaksud dalam Pasal 9 ayat (3) huruf b belum atau tidak mampu mendukung kegiatannya, penyelenggara telekomunikasi khusus dimaksud dapat menggunakan atau memanfaatkan jaringan telekomunikasi yang dimiliki dan atau digunakan oleh penyelenggara telekomunikasi lainnya.

(2) Ketentuan lebih lanjut sebagaimana dimaksud pada ayat (1) diatur dengan Peraturan Pemerintah.

Telekomunikasi khusus di dalam penjelasan pasal 29 ayat (3) UU No. 36 Tahun 1999 ini dapat diartikan sebagai handphone atau telepon genggam yang bertujuan untuk kepeluan persorangan seperti penjelasan ayat (4) bagian a.

Mengenai pengaturan hak dan kewajiban penyelenggara dan masyarakat diatur mulai pasal 12 ayat (1), (2), dan (3) sampai dengan pasal 22 ayat (1). Dalam lampiran Undang-Undang No. 36 tahun 1999 diuraikan sebagai berkut:

\section{Pasal 12}

(1) Dalam rangka pembangunan, pengoperasian, dan atau pemeliharaan jaringan telekomunikasi, penyelenggara telekomunikasi dapat memanfaatkan atau melintasi tanah Negara dan atau bangunan yang dimiliki atau dikuasai Pemerintah.

(2) Pemanfaatan atau pelintasan tanah negara dan atau bangunan sebagaimana dimaksud pada ayat (1), berlaku pula terhadap sungai, danau, atau laut, baik permukaan maupun dasar.

(3) Pembangunan, pengoperasian dan atau pemeliharaan jaringan telekomunikasi sebagaimana dimaksud pada ayat (1), dilaksanakan setelah mendapatkan persetujuan dari instansi pemerintah yang bertanggung jawab dengan memperhatikan peraturan perundang-undangan yang berlaku.

\section{Pasal 13}

Penyelenggara telekomunikasi dapat memanfaatkan atau melintasi tanah dan atau bangunan milik perseorangan untuk tujuan pembangunan, pengoperasian, atau pemeliharaan jaringan telekomunikasi setelah terdapat persetujuan di antara para pihak.

\section{Pasal 14}

Setiap pengguna telekomunikasi mempunyai hak yang sama untuk menggunakan jaringan telekomunikasi dan jasa telekomunikasi dengan memperhatikan peraturan perundang-undangan yang berlaku.

\section{Pasal 15}

(1) Atas kesalahan dan atau kelalaian penyelenggara telekomunikasi yang menimbulkan kerugian, maka pihak-pihak yang dirugikan berhak mengajukan tuntutan ganti rugi kepada penyelenggara telekomunikasi.

(2) Penyelenggara telekomunikasi wajib memberikan ganti rugi sebagaimana dimaksud pada ayat (1), kecuali penyelenggara telekomunikasi dapat membuktikan bahwa kerugian tersebut bukan diakibatkan oleh kesalahan dan atau kelalaiannya.

(3) Ketentuan mengenai tata cara pengajuan dan penyelesaian ganti rugi sebagaimana dimaksud 
pada ayat (1) dan ayat (2) diatur dengan Peraturan Pemerintah.

\section{Pasal 16}

(1) Setiap penyelenggara jaringan telekomunikasi dan atau penyelenggara jasa telekomunikasi wajib memberikan kontribusi dalam pelayanan universal.

(2) Kontribusi pelayanan universal sebagaimana dimaksud pada ayat (1) berbentuk penyediaan sarana dan prasarana telekomunikasi dan atau kompensasi lain.

(3) Ketentuan kontribusi pelayanan universal sebagaimana dimaksud pada ayat (2) diatur dengan Peraturan Pemerintah.

\section{Pasal 17}

Penyelenggara jaringan telekomunikasi dan atau penyelenggara jasa telekomunikasi wajib menyediakan pelayanan telekomunikasi berdasarkan prinsip:

a. perlakuan yang sama dan pelayanan yang sebaik-baiknya bagi semua pengguna;

b. peningkatan efisiensi dalam penyelenggaraan telekomunikasi; dan

c. pemenuhan standar pelayanan serta standar penyediaan sarana dan prasarana.

\section{Pasal 18}

(1) Penyelenggara jasa telekomunikasi wajib mencatat/merekam secara rinci pemakaian jasa telekomunikasi yang digunakan oleh pengguna telekomunikasi.

(2) Apabila pengguna memerlukan catatan/rekaman pemakaian jasa telekomunikasi sebagaimana dimaksud pada ayat (1), penyelenggara telekomunikasi wajib memberikannya.

(3) Ketentuan mengenai pencatatan/perekaman pemakaian jasa telekomunikasi sebagaimana dimaksud pada ayat (1) diatur dengan Peraturan Pemerintah.

\section{Pasal 19}

Penyelenggara jaringan telekomunikasi wajib menjamin kebebasan penggunanya memilih jaringan telekomunikasi lain untuk pemenuhan kebutuhan telekomunikasi.

\section{Pasal 20}

Setiap penyelenggara telekomunikasi wajib memberikan prioritas untuk pengiriman, penyaluran, dan penyampaian informasi penting yang menyangkut:
a. keamanan negara;
b. keselamatan jiwa manusia dan harta benda;
c. bencana alam;
d. marabahaya; dan atau
e. wabah penyakit.

\section{Pasal 21}

Penyelenggara telekomunikasi dilarang melakukan kegiatan usaha penyelenggaraan telekomunikasi yang bertentangan dengan kepentingan umum, kesusilaan, keamanan, atau ketertiban umum.

\section{Pasal 22}

Setiap orang dilarang melakukan perbuatan tanpa hak, tidak sah, atau memanipulasi:

a. akses ke jaringan telekomunikasi; dan atau

b. akses ke jasa telekomunikasi; dan atau

c. akses ke jaringan telekomunikasi khusus.
Masalah selanjutnya adalah mengenai sanksi dan ketentuan pidana. Sanksi administrasi diatur dalam pasal 46 yang berbunyi "Barang siapa melanggar ketentuan Pasal 16 ayat (1), Pasal 18 ayat (2), Pasal 19, Pasal 21, Pasal 25 ayat (2), Pasal 26 ayat (1), Pasal 29 ayat (1), Pasal 29 ayat (2), Pasal 33 ayat (1), Pasal 33 ayat (2), Pasal 34 ayat (1), atau Pasal 34 ayat (2) dikenai sanksi administrasi." Bentuk sanksi administrasi berupa pencabutan izin beroperasi kepada pihak penyelenggara yakni BUMN, BUMD dan perusahaan swasta. Hal ini sesuai dengan penjelasan pasal 46 ayat (1) dan (2).

Ketentuan pidana secara umum menurut UU No. 36 Tahun 1999 termuat dalam pasal 47, 48, 49, 50, 51, $52,53,54,55,56,57,58$, dan 59. Ketentuan pidana untuk kasus telekomunikasi khusus (handphone) diatur dalam pasal 51 yaitu "Penyelenggara telekomunikasi khusus yang melanggar ketentuan sebagaimana dimaksud dalam Pasal 29 ayat (1) atau Pasal 29 ayat (2), dipidana dengan pidana penjara paling lama 4 (empat) tahun dan atau denda paling banyak Rp.400.000.000,o0 (empat ratus juta rupiah).”

\section{Dampak Penggunaan Handphone di Kalangan Remaja Kota Mataram}

Dalam penggunaan handphone di kalangan remaja, kadang berdampak terhadap perubahan pada sikap dan perilaku dalam kehidupan mereka di seharihari. Jamani dkk, (2013: 11) melaporkan bahwa handphone merupakan hasil teknologi juga dirasakan oleh para siswa untuk menunjang ilmu pengetahuan, tetapi kurang tepat dalam menggunakan handphone dan berperilaku yang melanggar aturan sekolah. Siswa pengguna HP lebih senang SMS pada saat proses belajar mengajar, berkawan hanya kepada siswa yang mempunyai Handphone, mengambil dan mengirim gambar temannya saat berada di WC, sikap hidup individualistis, suka pindah tempat duduk di dalam kelas dan melakukan tindakan kriminal. Perilaku ini yang membuat tidak disiplin siswa pengguna Handphone.

Dalam penggunaan handphone di kalangan remaja kota mataram pada umumnya, berdampak terhadap perubahan pada sikap dan perilaku dalam kehidupan mereka di sehari-hari.

Nikmah (2010: 2-3) melaporkan bahwa handphone memiliki dampak positif dan negatifnya. Menurutnya, yang termasuk dampak positif dari Handphone diantaranya adalah:

1. Menambah pengetahuan tentang perkembangan teknologi.

Teknologi selalu berkembang sesuai dengan jaman dan pola pikir manusia yang selalu menuju kearah modernisasi.Oleh sebab itu ada baiknya juga jika siswa juga mampu mengikuti perkembangan teknologi dan informasi untuk pengetahuan siswa juga.

2. Mempermudah komunikasi terutama jarak jauh.

Untuk membantu siswa yang kesulitan dalam mengerjakan PR, Handphone bisa membantu menghubungi teman yang rumahnya jauh untuk bertanya PR karena dapat menghemat waktu.

3. Memperluas jaringan persahabatan.

Dengan menggunakan Handphone siswa bisa menambah teman dengan mudah melalui telepon langsung atau pesan singkat (SMS)

4. Sebagai penghibur pada saat siswa jenuh belajar. 
Dalam Handphone terdapat fitur - fitur MP3 atau game yang dapat memberi hiburan pada siswa sehingga apabila siswa mengalami kejenuhan dalam belajar siswa dapat mendengarkan musik atau sekedar main game.

5. Terdapat fitur internet yang dapat membantu siswa mencari informasi.

Hal ini mampu membantu siswa untuk mencari informasi atau materi pelajaran melalui fitur internet yang terdapat di Handphone.

6. Memiliki banyak memory.

Handphone memiliki banyak memory untuk menyimpan banyak data dengan mudah dan dapat dibawa kemana-mana, baik informasi materi pelajaran, foto - foto, video, hasil ujian, informasi tentang buku terbaru dan musik.Ini bisa digunakan untuk membantu dan mempermudah siswa memahami pelajaran.

Selain dampak positif dari penggunaan Handphone yang cukup banyak, namun cukup banyak juga dampak negatif bagi siswa yang patut di waspadai dan seharusnya di hindari, antara lain;

1. Terdapat efek radiasi yang mampu mempengaruhi kesehatan siswa, sehingga sebaiknya untuk anak SD jangan diberi Handphone untuk digunakan secara permanen.

2. Rawan tindak kejahatan, karena anak -anak di anggap kurang bisa menjaga diri menyebabkan anak - anak menjadi target utama dari kejahatan pencurian.

3. Mengganggu perkembangan anak, karena tidak jarang anak sekolah malah lebih tertarik melihat Handphone yang bergetar ketika pelajaran berlangsung. Parahnya lagi, Handphone digunakan untuk mencontek jawaban pada saat ujian akhir/nasional.

4. HP juga bisa mengakibatkan pemborosan, karena menambah pengeluaran untuk pulsa. Apalagi pulsa tersebut tidak digunakan dengan baik, maka akan membuang sia - sia pulsa tersebut.

5. Penyalahgunaan fitur internet

Internet yang selayaknya digunakan untuk mempermudah siswa mencari informasi atau materi pelajaran bisa disalah gunakan untuk mencari gambar atau video yang kurang baik (porno).

6. Menurunkan mental belajar siswa

Siswa kurang berani mengambil resiko dalam ujian, sehingga sering mencari jalan aman dengan mencontek teman melalui Handphone. Ini yang menjadikan minat belajar siswa juga berkurang yang mengakibatkan prestasi belajar siswa pun turun.

\section{Tinjauan Undang-Undang No. 36 Tahun 1999 Tentang Telekomunikasi terhadap Pengguna Handphone di Kalangan Remaja Kota Mataram}

Tinjauan UU No. 36 Tahun 1999 Tentang Telekomunikasi terhadap pengguna handphone di kalangan remaja kota Mataram dapat dipandang secara yuridis normatif.

Berdasarkan penjelasan Undang-Undang No. 36 tahun 1999 pasal 2 yakni "Telekomunikasi diselenggarakan berdasarkan asas manfaat, adil dan merata, kepastian hukum, keamanan, kemitraan, etika, dan kepercayaan pada diri sendiri”. Berdasarkan azas tersebut di dalam kehidupan remaja sangat membantu mereka dalam memanfaatkan handphone sebagai alat komunikasi dengan temannya, orang tua, maupun guru di lingkungan sekolah, dan lingkungan masyarakat. Hal ini dapat disesuaikan dengan pendapatnya Nikmah (2010: 2) yang menyatakan bahwa dampak positif dari penggunaan handphone dapat menambah pengetahuan, mempermudah komunikasi terutama jarak jauh, memperluas jaringan persahabatan, sebagai penghibur pada saat siswa jenuh belajar, terdapat fitur internet yang dapat membantu siswa mencari informasi, dan memiliki banyak memory.

Penggunaan handphone ini tidak hanya untuk siswa, tetapi juga utuk kalangan mahasiswa atau kaum intelektual lainnya selalu memanfaatkan handphone sebagai relasi komunikasi dengan teman sejawat ataupun dosennya. Oleh karena itu, menurut Hendrastomo, (2008: 9) menemukan bahwa terjadi pola komunikasi setelah kehadiran ponsel/handphone. Komunikasi antara dosen dan mahasiswa menemukan jalur baru dimana lebih mengedepankan aspek efektifitas, efesiensi, dan keterbukaan. Kemunikasi antara dosen dan mahasiswa adalah komunikasi yang dilakukan baik dari dosen kepada mahasiswa atau sebaliknya. Komunikasi ini meliputi hal-hal akademik (penyampaian tugas atau informasi akademik), pembimbingan, hingga penyambung tali silaturahmi. Ketika mahasiswa ingin bertemu dengan dosennya maka salah satu cara adalah dating ke rumah atau ke kantor, hubungan komunikasi sangat terbatas pada tatap muka, tidak heran dahulu banyak mahasiswa yang rela seharian menunggu dosen hanya untuk bertemu atau mendiskusikan sesuatu. Bagi dosenpun juga sama, untuk menginformasikan sesuatu hal kepada mahasiswa, mereka harus menggunakan media semisal pengumuman yang ditempel di papan pengumuman atau memberi memo yang disampaikan ke mahasiswa. Sebelum munculnya handphone, hubungan antara dosen dengan mahasiswa lebih pada hubungan langsung secara fisik melalui tatap muka. Selain itu diakui ketika handphone belum mewabah, cukup sulit untuk menyampaikan pesan dari dosen kepada mahasiswa.

Berdasarkan kedua pendapat di atas bahwa pengguna handphone baik siswa dengan guru, atau siswa dengan orang tua maupun mahasiswa dengan dosennya dapat memanfaatkan media komunikasi melalui handphone secara fungsional. Artinya bahwa dalam penjelasan pasal 2 Undang-Undang No. 36 tahun 1999 tentang telekomunikasi secara prinsipnya mampu menyesuaikan dengan sikap dan perilaku manusia sesuai aturan yang termuat di dalam undang-undang tersebut, sehingga undang-undang yang dibuat oleh pemerintah tidak sia-sia dangat bermafaat bagi keberlangsungan hidup masyarakat pengguna handphone.

Penggunaan handphone disamping memiliki dampak positif maka ada juga dampak negatifnya. Berdasarkan pendapat Nikmah (2010: 3) menemukan bahwa kelemahan dari penggunaan handphone di kalangan remaja bisa menyakibatkan terjadinya efek radiasi yang mempengaruhi kesehatan siswa, anak-anak dianggap kuran menjaga diri menyebabkan anak - anak menjadi target utama dari kejahatan pencurian, menggannggu kesehatan anak, handphone juga mengakibatkan pemborosan karena menambah pemborosan pulsa, penyalahgunaan fitur internet dengan menampilkan video yang tidak baik bahkan 
handphone juga bisa merekam perbuatan yang tidak baik (porno), dan bisa menurunkan mental belajar siswa akibat menggunakan tanpa keterbatasan waktu.

Secara yuridis, Undang-undang ini tidak mampu memberi batasan kreativitas seseorang dalam menggunakan handphone, hal ini bisa merusak sikap dan pola perilaku remaja dalam kehidupannya seharihari. Hal ini bisa kita melihat dampak-dampak negative penggunaan handphone di kalangan remaja. Apabila hal ini tidak diberikan ketegasan atau aturan hukum kepada pihak penyelenggara telekomunikasi ataupun badan usaha swasta yang bekerja bidang telekomunikasi, maka lambat laun generasi muda ke depan akan mengalami krisis moral dan sikap.

Beberapa penjelasan pasal per pasal atau point per poin ataupun bab per bab dalam uraikan UndangUndang No. 36 tahun 1999 tentang telekomunikasi ini tidak ditemukan pasal yang menjelaskan batasan umur pengguna handphone atau telepon seluler.

Undang-undang No. 36 Tahun 1999 tentang telekomunikasi hanya menjelaskan secara umum saja terkait dengan pengunaan dan pemakaian alat telekomunikasi khusus handphone. Hal ini sesuai dengan penjelasannya dalam Pasal 1 bahwa "Telekomunikasi adalah setiap pemancaran, pengiriman, dan atau penerimaan dari setiap informasi dalam bentuk tanda-tanda, isyarat, tulisan, gambar, suara dan bunyi melalui sistem kawat, optik, radio, atau sistem elektromagnetik lainnya;" kemudian diatur poin (g) mengatur Pengguna adalah pelanggan dan pemakai. Dalam ketentuan umum ini tidak satupun pasal yang menjelaskan batas umur pengguna atau pemakai alat telekomunikasi.

Jadi, disimpulkan bahwa Undang-undang No. 36 Tahun 1999 tentang telekomunikasi harus direvisi agar fungsi mengatur perilaku dan sikap manusia bisa efektif dan dan sangat bermanfaat bagi kalangan remaja.

\section{SIMPULAN DAN SARAN}

\section{SIMPULAN}

Berdasarkan hasil penelitian di atas disimpulkan bahwa adanya perubahan teknologi dan informatikan dapat memberi dampak positif dan negative pada pengguna handphone di kalangan remaja. Perubahan tersebut secara umumnya dipengaruhi oleh rasa keinginan tahuan terhadap benda baru mislanya menggunakan handphone sebagai alat telekomunikasi. Kemudian secara yuridis, Undang-undang No. 36 Tahun 1999 Tentang Telekomunikasi tidak mampu memberi batasan kreativitas seseorang dalam menggunakan handphone, hal ini bisa merusak sikap dan pola perilaku remaja dalam kehidupannya sehari-hari. Hal ini bisa kita melihat dampak-dampak negative penggunaan handphone di kalangan remaja. Karena Undang-undang ini hanya menjelaskan secara umum saja terkait dengan pengunaan dan pemakaian alat telekomunikasi khusus handphone.

\section{SARAN}

Sebaiknya pemerintah dan anggota legislative dapat mereduksi kembali pasal-pasal yang membahas batasan umur anak terhadap penggunaan Hnadphone, sehingga aplikasi dari perubahan Undang-Undang tersebut berperanan penting mengatur hubungan antara sesama pengguna atau hubungan pengguna dengan badan hukum sebagai penyelenggara jaringan telekomunikasi, dan juga menciptakan masyarakat taat hukum demi mencapai hakikat kehidupan aman, damai dan teratur.

\section{DAFTAR RUJUKAN}

Arminen, I. 2007. Review Essay Mobile Communication Society?. Acta Sociologica. Vol. 50, (4): 431-437.

Barker, C. 2008. Cultural Studies. Edisi Revisi. Yogyakarta: Kreasi Wacana.

Henslin, James M. 2006. Sosiologi dengan Pendekatan Membumi edisi 6 Jilid 2. Erlangga, Jakrta (diterjemahkan dari essential of Sosiology: a Down-toearth Approach $6^{\text {th }}$ Edition oleh Karmanto Sunarto).

Harper, Charles L. 1989. Exploring Social Change. London: Prentice Hall.

Hendrastomo, Grendi. 2008. Representasi Telepon Seluler dalam Relasi Sosial. Jurnal Sosial, Vol. 5, (2): 1-18.

Jamani, Hasan, Arkanudin, dan Syarmiati. (2013). Perilaku Siswa Penggunaan Handphone Studi Kasus Pada Siswa SMP Negeri 4 Sungai Raya Kabupaten Kubu Raya. Jurnal Tesis PMIS-UNTAN-PSS.

Lauer, Robert, H. 2003. Perspektif Tentang Perubahan Sosial. Jakarta: Rineka Cipta.

Nikmah, A. 2010. Dampak Penggunaan Handphone Terhadap Prestasi Siswa. E-Jurnal Dinas Pendidikan Kota Surabaya, Volume 3,: 1-8, ISSN: 2337-3253.

Mazdalifah. 2014. Sistem Komunikasi Indonesia di Tengah Arus Globalisasi. Artikel Jurnal, (Online), (https://mazdalifahjalil.wordpress.com/, diakses 02 Januari 2015.)

Martono, N. 2012. Sosiologi Perubahan Sosial, Prespektif Klasik, Modern, Posmodern, dan Poskolonial. Jakarta: Raja Grafindo Persada.

Moore, Wilbert E. 1967. Order and Change; Essays in Comparative Sociology. New York: John Wiley \& Sons.

Marzuki, Mahmud. P. 2005. Penelitian Hukum. Kencana: Jakarta.

Soekanto, S. dan Mamudji, S. 2010. Penelitian Hukum Normatif. Rajawali: Jakarta.

Veblen, Torstein. 1904. The Theory of Business Enterprise. New York: Charles Scribners Sons.

Undang-Undang Nomor $36 \quad$ Tahun 1999 Tentang Telekomunikasi. 